\title{
MANAGEMENT OF NONUNION OF FRACTURES BY DISTRACTION WITH CORRECTION OF ANGULATION AND SHORTENING
}

\author{
MICHAEL SALEH, SIMON ROYSTON \\ From the Northern General Hospital, Sheffield, England
}

W Te present a series of ten hypertrophic nonunions in which bony alignment and length were restored and union induced by external fixation and callus distraction. The mean length gained was $3.5 \mathrm{~cm}$ (1 to 6) and the mean angular correction was $13.5^{\circ}(0$ to 40). The mean treatment time was 10.2 months (3 to 15) and mean follow-up was 40 months (6 to 71 ). There have been no refractures or loss of correction or length.

The technique of callus distraction at a site of hypertrophic nonunion can correct shortening and angulation as well as induce bony union. No extra equipment is needed beyond readily-available external fixation systems.

J Bone Joint Surg [Br] 1996;78-B:105-9.

Received 10 October 1994; Accepted after revision 26 January 1995

Ilizarov (1989) demonstrated that controlled distraction of a well-vascularised corticotomy will produce bone in the distraction gap. This principle has been widely applied in limb lengthening in which distraction-osteogenesis occurs at a surgical corticotomy (De Bastiani et al 1987). In this method the production of callus is abundant (Aronson and Harrison 1987; Tajana, Morandi and Zembo 1989) and of a quality indistinguishable from normal bone (Saleh et al 1993).

Ilizarov also stated that callus at any site, including a fracture or a nonunion, can be distracted in a similar fashion and will undergo consolidation and maturation.

M. Saleh, MSc, FRCS, Professor of Orthopaedic and Traumatic Surgery Limb Reconstruction Service, University Department of Surgical Sciences, Northern General Hospital NHS Trust, Herries Road, Sheffield S5 $7 \mathrm{AU}, \mathrm{UK}$.

S. Royston, FRCS, Orthopaedic Registrar

Department of Orthopaedics, Chesterfield and North Derbyshire Royal Hospital, Calow, Chesterfield, Derbyshire S44 5BL, UK.

Correspondence should be sent to Professor M. Saleh.

(C)1996 British Editorial Society of Bone and Joint Surgery 0301-620X/96/11030\$2.00
Hypertrophic nonunion often has a high intrinsic mechanical strength which must be overcome before distraction can be performed. Ilizarov achieved this by a percutaneous osteotomy, a technique which he called metaphysiolysis.

Angular correction is achieved simply by selective unequal lengthening, and appropriate distraction of callus at a site of nonunion can be used to correct angular deformity as well as to obtain length. The technique has been referred to in other publications (Paley et al 1989; Saleh 1992). We describe ten patients with hypertrophic nonunion with shortening and angulation which was treated successfully by callus distraction.

\section{PATIENTS AND METHODS}

In our series there were nine men and one woman; they had a mean age of 33.5 years (19 to 66). There was nonunion of a fracture of the femur in four and of the tibia in six (Table I). The duration of nonunion ranged from 4 months in case
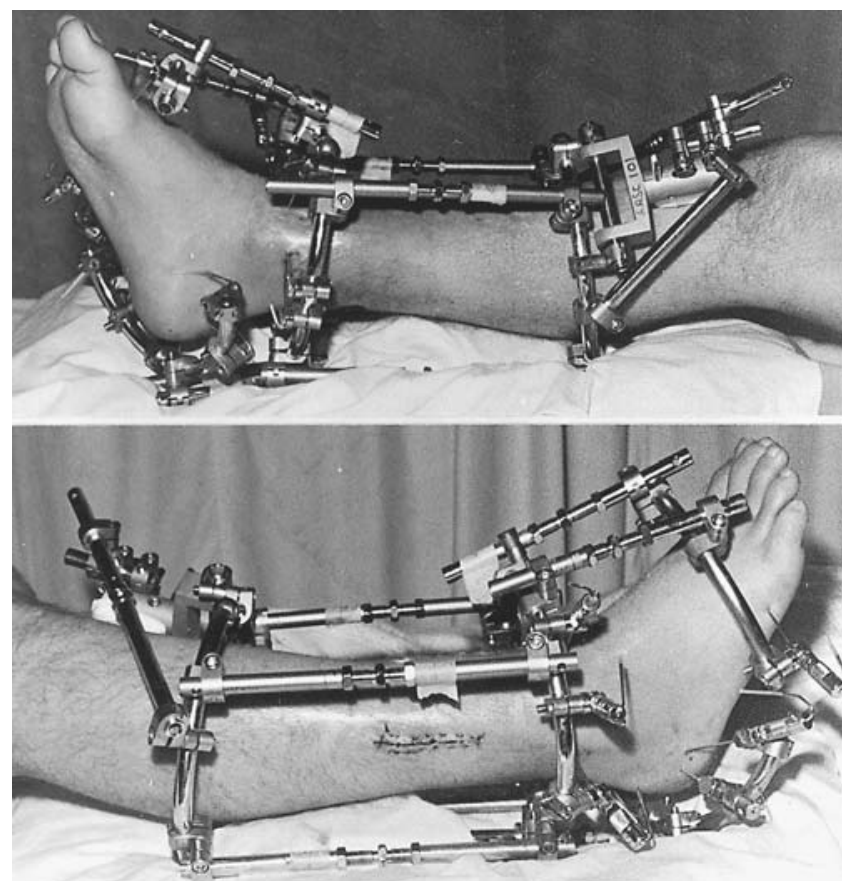

Fig. 1

The circular frame is extended on to the foot allowing the distal tibial fracture to be controlled while the equinus deformity is corrected. 


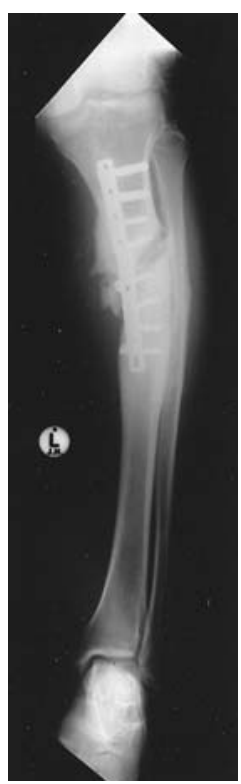

Fig. 2a

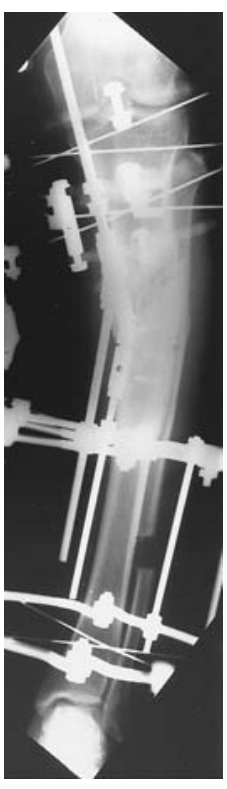

Fig. $2 b$
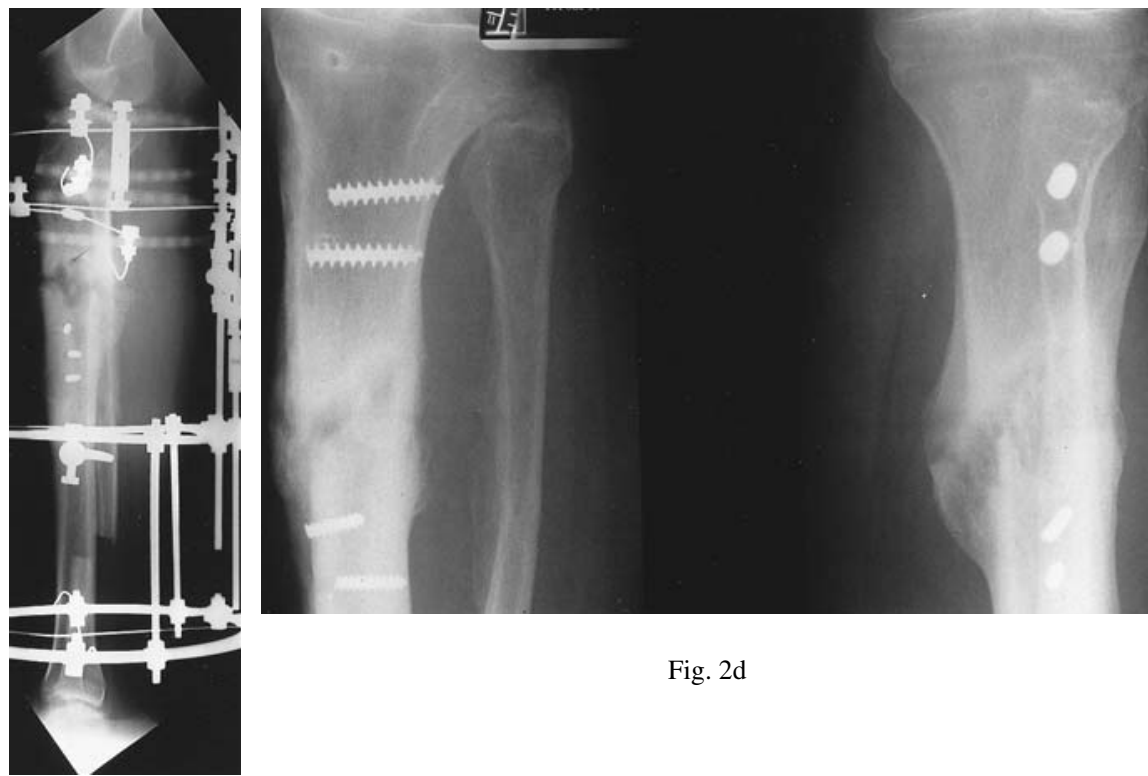

Fig. 2d

Case 10. Figure $2 \mathrm{a}$ - Radiograph at presentation showing a hypertrophic nonunion of the proximal tibia after failed plating. There is angulation of $20^{\circ}$ and shortening of $3 \mathrm{~cm}$. Figure $2 \mathrm{~b}$ - Immediate postoperative radiograph after partial removal of the metal and application of a circular frame. Figure $2 c-$ After progressive correction of angulation. Figure $2 d-$ After removal of the frame showing bony union and correction of deformity. An angular correction of $20^{\circ}$ and a length gain of $3 \mathrm{~cm}$ were achieved.

2 to 49 years in case 3 . All patients had had at least two previous operations to attempt to achieve union (Table I), except for case 3 who had been treated conservatively. Infection had been present at the fracture site in six patients (cases 1, 2, 4, 7, 8 and 10), but was not active at the time of distraction. Case 2 had a nonunion of a fracture through an area of the left femur affected with previous osteomyelitis, but there was no residual evidence of active infection.

We used unilateral fixation (Orthofix; Bussolengo, Verona, Italy) in three patients and circular fixation in seven. The former was preferred because it is simpler to apply and is better tolerated by patients. The indications for the use of tensioned wire circular fixators were proximity to a joint, soft bone or an oblique plane of angular deformity. When the nonunion was in the distal tibia or there was an equinus deformity the circular frame was extended on to the foot (Fig. 1). In five of the six cases of tibial nonunion, we performed a fibular osteotomy to allow distraction. Stiff hypertrophic nonunions underwent percutaneous osteotomy when necessary (cases 3 and 4). Osteotomes were inserted into the fracture line under radiological control and passed through the soft interzone until fracture mobility was induced. The fixator was then mounted and the nonunion left approximated.

Distraction was begun between 5 and 14 days later at a rate of 0.25 to $1.0 \mathrm{~mm} /$ day in $0.25 \mathrm{~mm}$ increments, depending on the character of the fracture. When necessary eccentric distraction was performed first to correct angulation and, when alignment was satisfactory, linear distraction was substituted to regain length.

The amount of length gained, the angular correction and the quality of the regenerated bone were monitored radiologically. Distraction was stopped when sufficient angular correction and gain of length had been achieved. The fixator was left in position for a further period to allow consolidation of the callus and removed when union was judged to be complete.

\section{RESULTS}

All the fractures united successfully after a mean of 10.2 months ( 3 to 15) of treatment. Figures 2 and 3 show typical examples.

The mean length gained was $3.5 \mathrm{~cm}$ (1 to 6) and the mean angular correction was $13.5^{\circ}$ (0 to 40 ). In case 3 whose nonunion was of extreme duration, angular correction was deliberately incomplete because of reciprocal changes in the joints of the hindfoot.

The bone healing index, which is the duration of treatment divided by the length gained $(\mathrm{mth} / \mathrm{cm})$, ranged from 1.5 to 15 (mean 5.1) (Table II).

The patients have been followed up for a mean of 40 months (6 to 71) from removal of the fixator with no loss of correction or refracture.

\section{DISCUSSION}

The basic principles of the management of nonunion have been described previously (Saleh 1992; Ribbans Stubbs and 

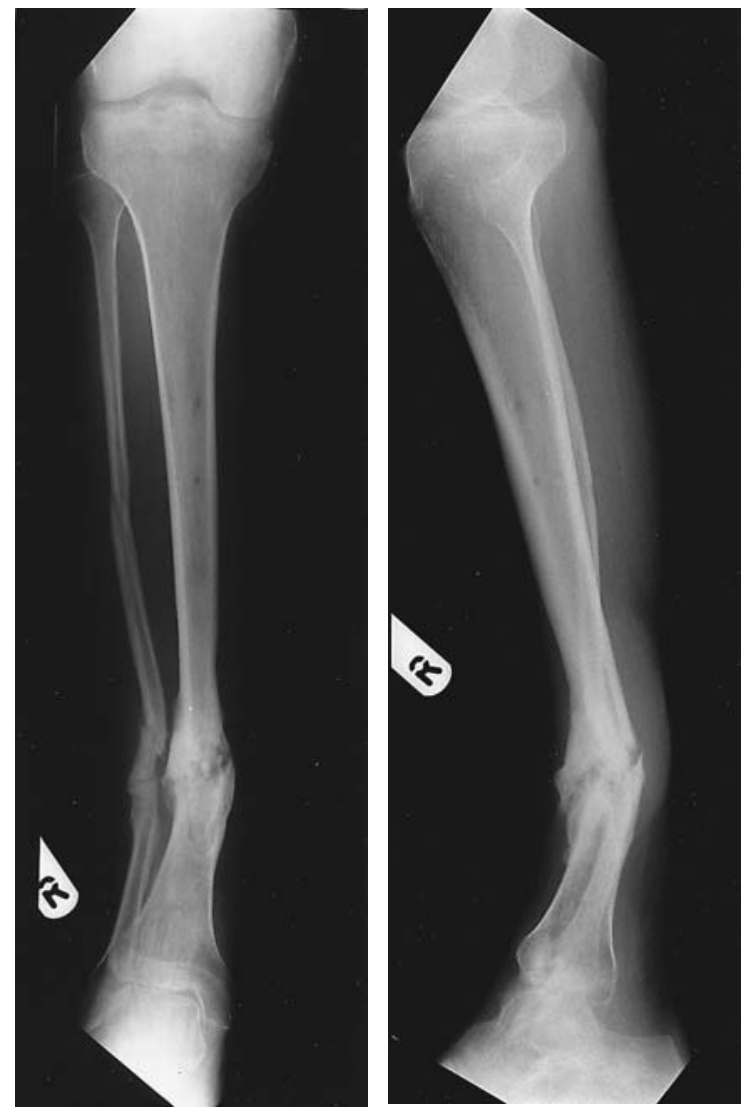

Fig. 3a

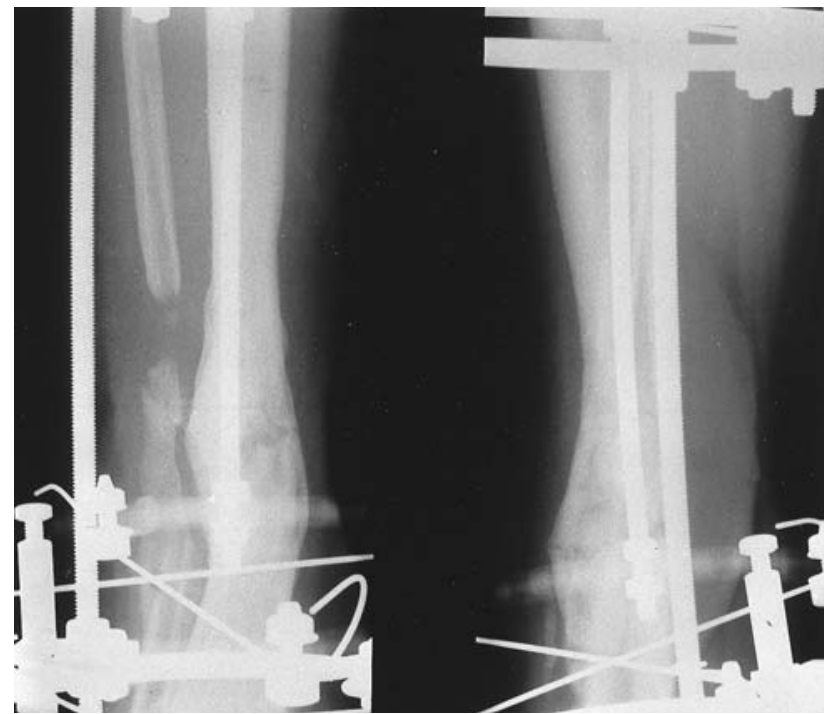

Fig. 3d

Case 8. Figure $3 \mathrm{a}$ - Radiograph showing hypertrophic nonunion with angulation of $20^{\circ}$, shortening of $1 \mathrm{~cm}$ and an equinus deformity. Figure $3 b-$ After correction of the deformity. Figure $3 c-$ Coned view of the site of nonunion during consolidation showing maturing callus in the distraction gap. Figure $3 \mathrm{~d}$ - Corresponding views taken shortly before removal of the fixator showing mature bridging callus. Figure $3 \mathrm{e}-$ Twelve months after removal of the fixator. The correction of length and angulation has been maintained and the ankle is in a neutral position.

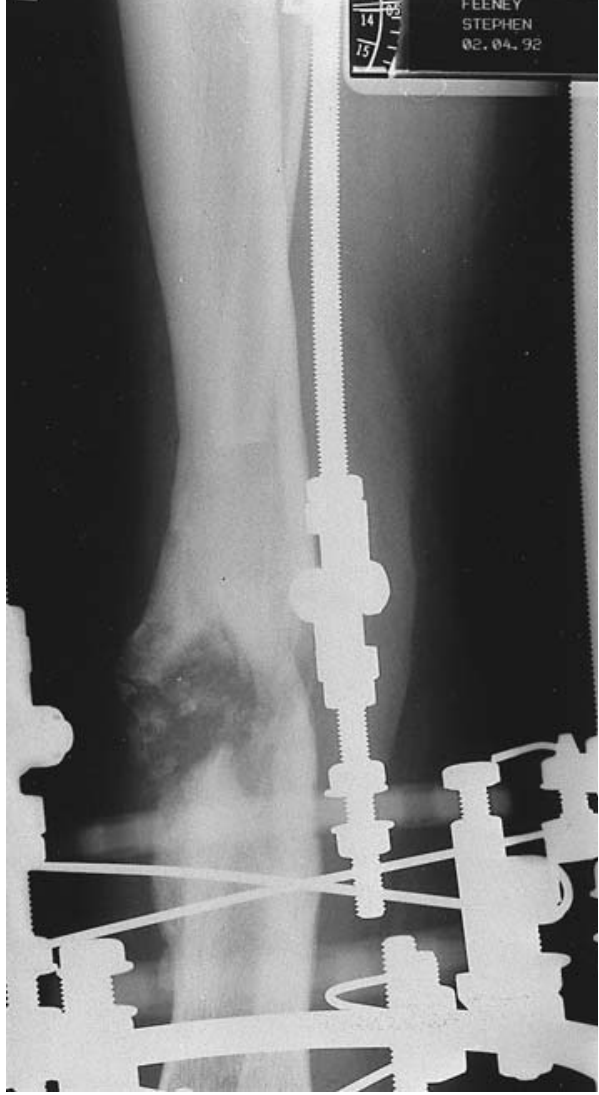

Fig. 3b

Fig. 3c
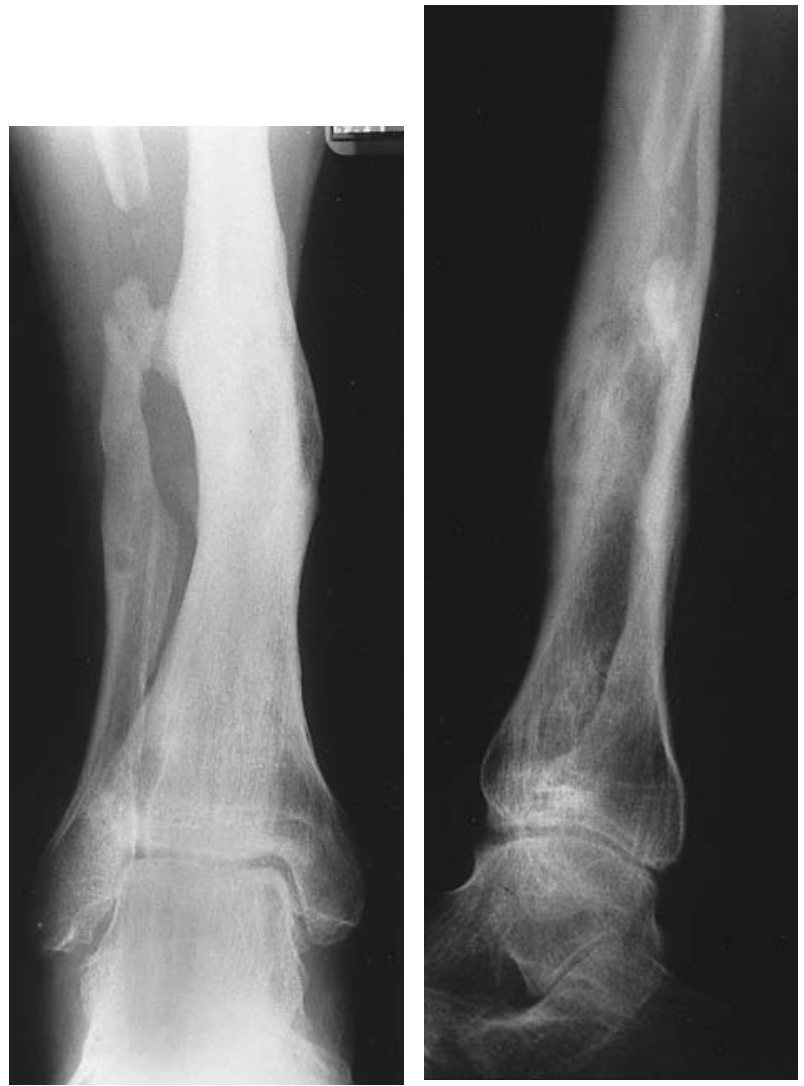

Fig. 3e 
Table I. Details of ten patients who had external fixation and callus distraction

\begin{tabular}{|c|c|c|c|c|c|c|c|c|}
\hline Case & Sex & $\begin{array}{l}\text { Age } \\
(\mathbf{y r})\end{array}$ & Bone & $\begin{array}{l}\text { Duration of } \\
\text { nonunion } \\
\text { (mth) }\end{array}$ & $\begin{array}{l}\text { Previous } \\
\text { surgery/ } \\
\text { treatment* }\end{array}$ & $\begin{array}{l}\text { Previous } \\
\text { sepsis at } \\
\text { nonunion } \\
\text { site }\end{array}$ & $\begin{array}{l}\text { Angulation } \\
\text { (degrees) } \dagger\end{array}$ & $\begin{array}{l}\text { Shortening } \\
\text { (cm) }\end{array}$ \\
\hline 1 & $\mathrm{M}$ & 50 & Tibia & 85 & $\begin{array}{l}\text { MUA X2 } \\
\text { BG X2 } \\
\text { Ex Fix X2 } \\
\text { PEMF X2 } \\
\text { Other X2 }\end{array}$ & Yes & 30 & 4 \\
\hline 2 & $\mathrm{M}$ & 19 & Femur & 4 & $\begin{array}{l}\text { Ex Fix } \\
\text { Other X2 }\end{array}$ & Yes & 0 & 2 \\
\hline 3 & $\mathrm{M}$ & 66 & Tibia & 600 & $\begin{array}{l}\text { MUA } \\
\text { POP }\end{array}$ & No & 20 & 5 \\
\hline 4 & $\mathrm{M}$ & 32 & Tibia & 29 & $\begin{array}{l}\text { ORIF } \\
\text { Ex Fix } \\
\text { Flap } \\
\text { Other X2 }\end{array}$ & Yes & 0 & 1 \\
\hline 5 & $\mathrm{M}$ & 20 & Femur & 48 & $\begin{array}{l}\text { Traction } \\
\text { Cast brace }\end{array}$ & No & 30 & 7 \\
\hline 6 & M & 22 & Femur & 23 & $\begin{array}{l}\text { Ex Fix } \\
\text { POP spica }\end{array}$ & No & 10 & 7 \\
\hline 7 & $\mathrm{M}$ & 29 & Tibia & 37 & $\begin{array}{l}\text { MUA } \\
\text { ORIF X2 } \\
\text { BG X2 } \\
\text { Other }\end{array}$ & Yes & 40 & 5 \\
\hline 8 & $\mathrm{M}$ & 33 & Tibia & 18 & $\begin{array}{l}\text { Ex Fix } \\
\text { ORIF } \\
\text { Flap } \\
\text { Other } \\
\text { BG }\end{array}$ & Yes & 20 & 1 \\
\hline 9 & F & 31 & Femur & 17 & $\begin{array}{l}\text { MUA } \\
\text { ORIF } \\
\text { IMN } \\
\text { Other X2 }\end{array}$ & No & 10 & 6 \\
\hline 10 & $\mathrm{M}$ & 33 & Tibia & 18 & $\begin{array}{l}\text { Ex Fix } \\
\text { ORIF } \\
\text { Flap } \\
\text { BG }\end{array}$ & Yes & 20 & 3 \\
\hline
\end{tabular}

Table II. Results of external fixation and callus distraction in ten patients

\begin{tabular}{lllllll}
\hline Case & $\begin{array}{l}\text { Fixator } \\
\text { type* }\end{array}$ & $\begin{array}{l}\text { Angular } \\
\text { correction } \\
\text { (degrees) } \dot{\dagger}\end{array}$ & $\begin{array}{l}\text { Length } \\
\text { gain } \\
(\mathbf{c m})\end{array}$ & $\begin{array}{l}\text { Duration of } \\
\text { treatment } \\
\text { (mth) }\end{array}$ & $\begin{array}{l}\text { Bone } \\
\text { healing } \\
\text { index } \neq\end{array}$ & $\begin{array}{l}\text { Follow-up } \\
\text { (mth) }\end{array}$ \\
\hline 1 & CIRC & 10 & 1 & 8 & 8.0 & 71 \\
2 & CIRC & 0 & 2 & 3 & 1.5 & 71 \\
3 & CIRC & 10 & 5 & 8 & 4.0 & 63 \\
4 & CIRC & 0 & 1 & 10 & 10.0 & 57 \\
5 & DAF & 15 & 5 & 8 & 1.5 & 47 \\
6 & DAF & 10 & 6 & 13 & 2.2 & 26 \\
7 & CIRC & 40 & 5 & 10 & 2.0 & 26 \\
8 & CIRC & 20 & 1 & 15 & 15.0 & 19 \\
9 & DAF & 10 & 6 & 14 & 2.5 & 17 \\
10 & CIRC & 20 & 3 & 13 & 4.3 & 6 \\
\hline
\end{tabular}

* CIRC, circular frame; DAF, Orthofix external fixator

$\dagger$ only the largest angular correction in a single plane is given for each patient

\$ see text 
Saleh 1992). Charnley (1968) and Müller, Allgöwer and Willenegger (1963) emphasised the importance of compression at a fracture site in achieving union, and distraction is thought to predispose to nonunion (Heiple and Herndon 1965). Fracture distraction across joints (ligamentotaxis), however, has been described for peri- and intra-articular fractures and has achieved good results (Vidal et al 1977).

Our series has shown that nonunions which are initially approximated can heal in distraction under appropriate conditions. Distraction may be continued to correct shortening and non-linear distraction may be used to overcome angular deformity.

The choice of the external fixation device has no apparent influence on the outcome and little additional equipment is required provided that the fixator is capable of gradual elongation. Correcting complex deformities may be accomplished most easily with a circular frame. No major operation is required to undertake distraction osteogenesis in a suitable case.

There have been many reports of distraction osteogenesis in surgically-produced osteotomies (Delloye et al 1990; Saleh et al 1993); distraction of fracture callus has much in common with this but the precise biological mechanism is unclear.

Ilizarov believed that the ability of callus to proliferate under tension merely reflects a capability present in all tissues under conditions of suitable stability, adequate vascularity and functional use. The only prerequisite for callus distraction at a fracture or nonunion is that the bone can produce callus. Unlike other tissues, however, bone is capable of healing by regeneration of its tissues under normal conditions, most of its surfaces being covered by cells capable of osteogenesis if appropriately stimulated (Matthews 1980; Simmons 1980).

Hypertrophic changes at a nonunion prove that this callus-forming capacity is present, and all that is required in such cases is appropriate manipulation of the mechanical environment to allow the callus to mature and remodel.

If it is assumed that reduction or abolition of shear forces rather than compression is needed for successful healing, it can be understood that this can be achieved by mechanically-competent external fixation, bony realignment and soft-tissue tension. Distraction osteogenesis can successfully produce bony union while simultaneously correcting length and angulation. Callus of good quality is obtained and we have seen no refractures or loss of correction in our patients.

No benefits in any form have been received or will be received from a commercial party related directly or indirectly to the subject of this article.

\section{REFERENCES}

Aronson J, Harrison B. Mechanical induction of osteogenesis by distraction of a metaphyseal osteotomy in long bones. Orthop Trans 1987;12:106-16.

Charnley J. The closed treatment of common fractures. Edinburgh: Livingstone, 1968.

De Bastiani G, Aldegheri R, Renzi-Brivio L, Trivella G. Limb lengthening by callus distraction (callotasis). $J$ Pediatr Orthop 1987;7:129-34.

Delloye C, Delefortrie G, Coutelier L, Vincent A. Bone regenerate formation in cortical bone during distraction lengthening: an experimental study. Clin Orthop 1990;250:34-42.

Heiple KG, Herndon CH.The pathologic physiology of nonunion. Clin Orthop 1965; 43:11-21.

Ilizarov GA. The tension-stress effect on the genesis and growth of tissues: part I. The influence of stability of fixation and soft-tissue preservation. Clin Orthop 1989;238:249-81.

Matthews JL. Bone structure and ultrastructure. In: Urist MR, ed. Fundamental and clinical bone physiology. Philadelphia: JB Lippincott, 1980:4-44.

Müller ME, Allgöwer M, Willenegger H. Technik der operativen Frakturen Behandlung. Berlin etc: Springer-Verlag, 1963.

Paley D, Catagni MA, Argnani F, et al. Ilizarov treatment of tibial nonunions with bone loss. Clin Orthop 1989;241:146-65.

Ribbans WJ, Stubbs DA, Saleh M. Non-union surgery. Part II. The Sheffield experience: one hundred consecutive cases. Results and lessons. Int J Orthop Trauma 1992;2:19-24.

Saleh M. Non-union surgery. Part I. Basic principles of management. Int J Orthop Trauma 1992;2:4-18.

Saleh M, Stubbs DA, Street RJ, Lang DM, Harris SC. Histologic analysis of human lengthened bone. J Pediatr Orthop 1993; 2:16-21.

Simmons DJ. Fracture healing. In: Urist MR, ed. Fundamental and clinical bone physiology. Philadelphia: JB Lippincott 1980:283-330.

Tajana GF, Morandi M, Zembo MM. The structure and development of osteogenetic repair tissue according to Ilizarov technique in man: characterization of extracellular matrix. Orthopedics 1989;12:515-23.

Vidal J, Buscayret C, Fischbach C, et al. A new method of treatment of comminuted fractures of the lower end of the radius: 'ligamentary taxis'. Acta Orthop Belg 1977;43:78-9. 